\title{
A Study of the Contemporary Portuguese Stained Glass: Artists and Works
}

\author{
Teresa Almeida ${ }^{1,2}$ \\ ${ }^{1}$ Vicarte Research Unit "Glass and Ceramics for the Art”, Nova School of Science \& Technology, Lisbon, Portugal \\ ${ }^{2}$ i2ads Research Institute in Art, Design and Society Faculty of Fine Art, Porto University, Porto, Portugal
}

Email address:

talmeida@fba.up.pt

\section{To cite this article:}

Teresa Almeida. A Study of the Contemporary Portuguese Stained Glass: Artists and Works. International Journal of Architecture, Arts and Applications. Vol. 7, No. 2, 2021, pp. 24-32. doi: 10.11648/j.ijaaa.20210702.11

Received: February 20, 2021; Accepted: March 18, 2021; Published: April 30, 2021

\begin{abstract}
The qualities of glass as transparency, translucence, brightness and versatility for the various applications, practical and aesthetics make this material indispensable for the artistic creation with a close connection with architecture. In an historical approach this paper will succinctly study the tradition and charisma of this light material, giving special credit to the stained glass, demonstrate the emerge of this Art in the relation with architecture, concerning the Portuguese contemporary panorama. Portugal has a history regarding contemporary stained glass that is unknown. In the $20^{\text {th }}$ century we assist to an interest and development in this art, as many recognized Portuguese artist, painters and sculptures contribute to this mural art, conceiving cartoons and maquettes that would be produce in glass studios, some of them in Portugal, in a close relationship between artists and craftsmen. Born in association with architecture, stained glass is much more than a simple decoration of space, it is an integral part of the architectural building. This paper will focus on the production of stained glass in Portugal, showing some significant examples of works produced by Portuguese renowned artists. Colorful windows with grisailles paintings in an association between color and light will be presented, and also the changes that happen during the $20^{\text {th }}$ and $21^{\text {st }}$ centuries, clarifying the state of Portuguese stained glass.
\end{abstract}

Keywords: Stained Glass, Portuguese Artists, Case Studies, Glass and Architecture

\section{Introduction}

The stained glass is a kinetic painting; our perception changes as the light changes. The use of colored glasses acted as a filter that transformed daylight [1] and until today this art still continues to perform this function. The artist who works in the art of stained glass paints with light [2], and is often limited to the window space in which the stained glass is confined, thus establishing a unique relationship with the surrounding architecture.

Stained glass emerges in religion buildings from Middle Age, and like frescoes, low reliefs, wood carvings and mosaics from this period was conditioned to this dogma [3]. The themes were theological and this art function as an illustrative bible, a literacy and culture for the faithful who could not read, by showing the stories about biblical passages or the life of saints. The congregation who attended these religious spaces, comprehended the experience of the matters depicted in the windows.

Today, stained glass is a medium for fine art, it is not only related to ecclesiastic building, and the themes are very wide. We can visualize this art in many architectural buildings both practical and public. The role of the artists is important. In contrast to what happened in the Middle Ages, a time when the artist was an anonymous element in a work team, currently the artist expresses autonomously [2], the pictorial language characteristic of their artistic works, namely in painting on canvas is expressed in this medium.

This paper provides a historical overview on Portuguese stained glass focusing on the 20th and 21 st century, presenting glass studios and works made from prominent Portuguese artists. The selective examples display a vast variety of this medium and an overview of the contemporary stained glass in Portugal.

\section{History and Tradition of Stained Glass in Portugal}

Portugal has a history regarding stained glass, however not 
as vast as other countries such France, England or Germany. According to the historian Pedro Redol, the first example of a stained glass windows in Portugal date from the $15^{\text {th }}$ century and are displayed in the Holy Mary Victoria (Santa Maria de Vitória) Monastery in Batalha [4].

The historian Carlos Barros says that stained glass is an essentially Gothic phenomenon and Portugal, at that time, did not have favorable economic conditions for the construction of large cathedrals, nor the possibility of bringing in foreign masters [5]. For this reason, the widespread installation of this art is not as common in the territory as other arts.

It was not until the 20th century that there was a significant development of this art, with countless works of artistic quality completed by famous Portuguese artists and the emergence of stained glass studios, such as Ricardo Leone in 1904 in Lisbon, and Vidraria Antunes in 1906 in Porto.

The first studio was founded by Cláudio Martins operated until 1971. In 1913 the workshop passed to Martin's disciple Ricardo Leone, who took the overall command of it in 1920. With this new orientation, the painters Conceição Silva, Mário Costa and other notable artists such as Almada Negreiros, Abel Manta, Jorge Barradas and Lino António collaborated. It was at this workshop that they made their cartoons for several stained glass windows. Ricardo Leone works are distributed throughout the country and also in the former colonies, namely Angola, Mozambique and Guinea. The golden period of this workshop was between the 1920s and 1940s. At this time Ricardo Leone saw his works distinguished with prizes including the Milan Gold Medal (1920), the Rio de Janeiro Grand Prix (1923) and the Grand Prix of Seville (1929). In 1933, he produced the Abel Manta cartoons, the great stained glass for the Portuguese National Statistics Institute, and in 1936, the Almada Negreiros cartoons for the stained glass windows of the Church of Our Lady of Fatima (Nossa Senhora de Fátima) in Lisbon [6].

In Porto, the stained glass studio was founder by Plácido António Antunes and the manufacture created in this workshop is immense and for more than a century it has been operational, presently being the oldest workshop in Portugal that remains in operation today [7]. It is a family workshop, Plácido Antunes passed the workshop to his son João Baptista Antunes in 1939 assume overall responsibility [8]. It is now in its third generation with João Aquino Antunes. This studio also worked with numerous renowned Portuguese artists. The stained glass works installations are more concentrated in the North of the country and are related to ecclesiastical entities, law courts, town halls, hospitals and private residences or collections, however this studio also did work abroad. One of the first examples of this studio can be seen at the Church of Congregates Saint Antony (Santo António dos Congregados) in Porto, commissioned in 1925 and finished 1927 [9]. The quality and quantity of the work produced is of great importance and for that reason a museum of stained glass, Museu do Vitral, will open in 2021 displaying the collection of this studio.

Each studio has its own characteristics, it can be said that grisaille painting is characteristic of the studio where the stained glass was created, as a token of authenticity [10]. Individually studios have their own language and expression, sometimes we can easily identify the works from each of them. These can also be recognized by the glass color used, the way the glass shape was cut, or the lead line composition, as well as the grisaille painting.

Many Portuguese artists are still developing stained glass windows, and this art presents a diverse possibility for them to express their aesthetics conception in a different medium. For all these reasons, stained glass is much more than a simple decoration of space, it is an integral part of the architectural building.

\section{Almada Negreiros the First Example of Contemporary Stained Glass}

Belonging to the generation of artists who introduced modernism to the country, Almada Negreiros (1893-1970) has been considered the backbone of Portuguese modernism. He developed a vast number of artistic works, not only in painting but also in ceramics, tapestry, mosaic and stained glass.

With regard to the stained glass windows, he conceived within a full of strength and color, consisting of a rigorous and innovative design a work for the Church of Our Lady of Fatima (Nossa Senhora de Fátima,) Lisbon in 1934-38. This stained glass is a religious theme and although figurative, of a medieval nature, the composition has a modern conception. The gray painting is expertly done, transmitting emotions on the faces of the figures, developing volumes in the draperies and images. On the main façade, over the choir pit is a large triptych, with the theme of the Holy Trinity and Christ crucified surrounded by angels. On each side of the central nave there are five crevices, narrow and high, where Almada configured several invocations of the Virgin Mary. Slender figures intertwine with biblical scenes. Here we can see a certain constructivism in the composition, where luminous values attributed by the color of the stained glass bring the composition to life. Finally, behind the High Altar, in the apse, there is an assembly of angels under a starry sky, like a celestial vault, constituting a celestial orchestra [11] as shown in Figure 1.

According to the historian Maria Augusta Maia the expressions, gestures and colors of the wings remove us from the classic canons and make us complicit in the Painter's lyrical dynamics [12]. The Almada stained glass works were a rediscovery of a forgotten tradition and allowed an opportunity for fine artists to find a new source of creation [13]. Almada Negreiros understood the potential of stained glass. These works are a mark, as allowed a resurgence of a disregarded art introducing contemporary stained glass in Portuguese Art history. The artistic result of the stained glass was quite surprising, which made the architect Pardal Monteiro order from him other works such as the stained glass for the Greater seminar of King Christ (seminario Maior de Cristo Rei) in 1959. 


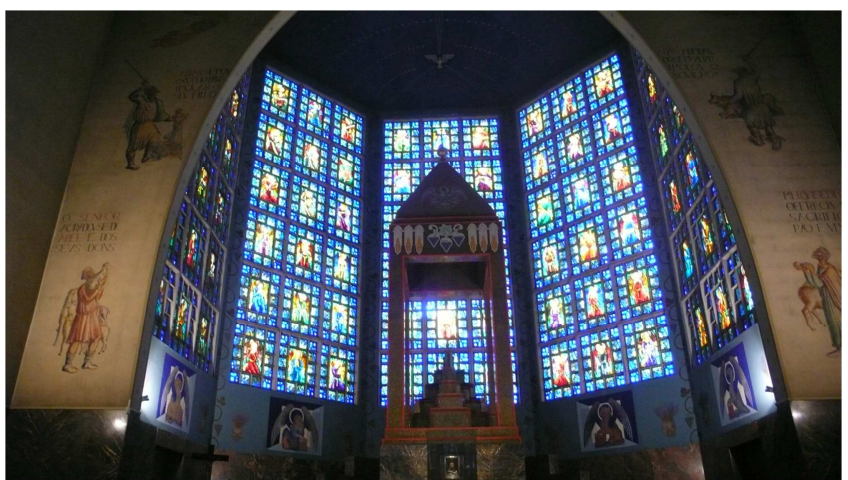

Figure 1. Almada Negreiros, Church of Our Lay of Fatima, Lisbon, 1934-38.

\section{Figurative Composition in Ecclesiastical Buildings}

In the 1950s, with the establishment of the Religious Art Renewal Movement (Movimento de Renovação da Arte Religiosa - MIRAR), we witnessed the emergence of a new sacred art, as a revivalist reaction and in defense of the concepts of modern architecture and the appropriation of a new artistic canons [14]. Fine art artists, with academic training, namely from the Faculties of Fine Arts of Porto and Lisbon universities, with a consolidated artistic career, made stained glass works for ecclesiastical buildings. In many of the stained glass windows made by these artists, the pictorial language characteristic of their artworks, in most cases painting on canvas, is expressed. These artists developed works that occupy a prominent place in the sphere of Portuguese Contemporary Art integrated in architecture, demonstrating the liveliness and importance of this 'sui generis' way of painting.

In 1954, Júlio Pomar (1926-2018) made the cartoons for the Pontinha Church stained glass (Figure 2), in Odivelas $(10 \mathrm{~km}$ northwest of Lisbon). It is a set of twelve stained glass windows. In the main facade we see that the figurative is evident in the personification of the Holy Family, the other stained glass windows have other Saints. There is a linear care in the contours of the slender figures that occupy the central composition of the stained glass, and in the chromatic play created by light and color. The figures seem to protrude from the bottom, as if levitating. The faces are calm, and the design of the clothes has a stylized character, in the sense that they do not have their frequent attributes [15].

The lead lines are a construction factor in the stained glass composition, not only drawing the images, but also creating a formal composition with the background. The compositions are developed in unique planes, with figures occupying the entire verticality of the works. At the bottom of the compositions, linear geometrical structures give rise to facets where small monochromatic variations develop which, due to their unity, enhance and facilitate the reading of the figures represented [7]. The drawing, which has always interested Pomar and is present in his painting works on canvas, can also be seen in the linear composition "in pencil, pen, charcoal, directly in brush, with markers, with scissors" [16].

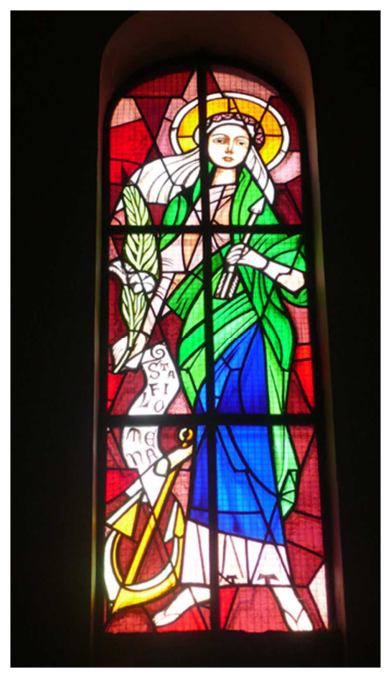

Figure 2. Júlio Pomar satined glass, Pontinha Church, 1954.

The stained glass made in 1959 for the Chapel of Palace of the Dukes of Bragança in Guimarães with the signature of António Lino (1914-1996) demonstrates a relationship between history and religion (Figure 3). The iconography is related to the history of Portugal and the city of Guimarães [7]. Guimarães is a UNESCO world heritage center and the cradle of the Portuguese nation. Palace of the Dukes was built by D. Afonso (son of King D. João I) in 1420 and in 1886 it was considered a unique example of the Iberian Peninsula [17]. The structure underwent restorations in the 1930s that lasted until 1960s [18].

The work is displayed in twelve stained glass windows built into two large windows, divided six in each. Here we can visualize a stylized medieval art in the diffusion of small fragments of colored glass. António Lino thought to integrate the stained glass technique used in the 14 th and early- $15^{\text {th }}$ centuries. Medieval fashion completed the theme of each figure with captions in red phylactery with the identification of the characters [19]. António Lino believed that all art of the Middle Ages was a form of thought and dressed that it is not separated from the "idea that created it and animates it: the soul" [20].

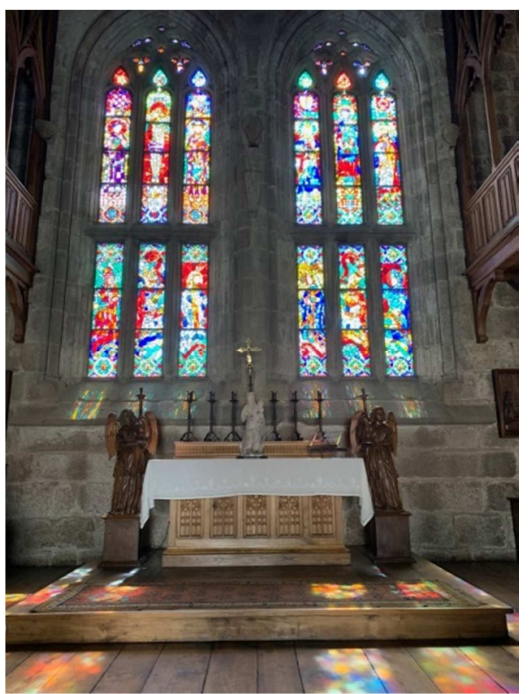

Figure 3. António Lino stanaid glass, Palace of the Dukes of Bragança, Guimarães, 1959. 
In the Church of Our Lady of Boavista (Nossa Senhora da Boavista) in Porto, the stained glass windows of 1981, by Júlio Resende (1917-2011) (Figure 4), show a perfect harmony of the pictorial effects, where the incidence of light projects a singular luminosity inside the church. The chromatism obtained, both in the figures and in the background, establishes in the work, a relevant character in its formal composition. All of it has a movement that is characterized not only by the verticality of the small blue glasses, chromatically subdivided through the lead line, but also by the movement of the figures. Lead is used here as a structuring element in the composition, much more than a simple separator of unevenly colored glasses. The nature of abstract forms and conceptions, the characters built where black gray hair accentuates the drama of their faces, are a great example of modern Portuguese sacred art [21]. Resende had a particular interest in Mural Art and Mural Art painting, that he considered to be the painting of the future [22]. Resende was one of the greatest Portuguese artists., and according to Porfírio his work has two facets the expressionist and the lyrical "as a watercolorist in clear colors and broad brushstrokes, deconstructed forms and constant rebirth" [23] that subjugated in his work from 1970 onwards. The stained glass has a symbolism and a message regarding the parish community, and there is a thematic unit that allows to characterize them as a unitary whole. For that sense it as a double meaning it respects the stained glass tradition and presents a contemporary approach towards the motifs [14]. Julio Resende associates the image to the word and in the composition, we can read sentences that relate to the religiosity and the bible.

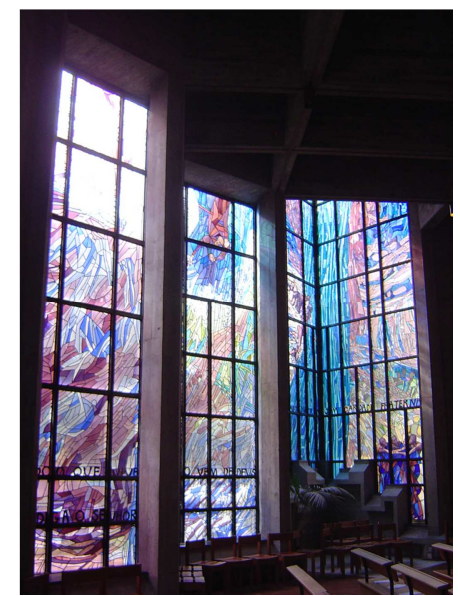

Figure 4. Júlio Resende stained glass, Church of Our Lady of Boavista (Nossa Senhora da Boavista), Porto. 1981.

\section{Government Buildings and Others}

In non-religious public buildings, stained glass often shows allegories about events regarding the life of that society, consuetude and traditions. This is the case of the Lino António (1898-1974) stained glass at Douro House made in 1945. Lino António participated in the first exhibition of the National Propaganda Secretariat (Secretariado de Propaganda Nacional
- SPN) in 1933, together with the painters Abel Manta, Abílio Leal de Matos e Silva, Albano Portocarreno de Almeida and António Soares. It is in the late 1930s that this artist began to participate in public orders from the state, namely, ceramic panels, frescoes, tapestries and stained glass [24]. In 1945 he produced the cartoons and stained glass for the Douro House in Régua, executed with the help of José Alves and António Alves Mendes [24]. The stained glass window has a traditionalist character, robust figures, where the composition seeks to be a description of the activities of Port wine (Figure 5). It is possible to visualize the expression of the faces of the figures in the brushstrokes of the gray hair, faces where one sees a typical effort of this hard work. The formal composition is well executed, in a single stained glass window it can demonstrate several labors. It is a stained glass window where the predominance of gray paint is clearly visible, assuming an important role in its composition. We have seen a great mastery of this technique, especially in gray paint, by the artist [7]. It can be seen in the stained glass, that next to the artist's signature, he made a point of mentioning that he "painted" the stained glass windows, so it was, and still is, the author of the cartoons most of the times does not participate in the execution that are made on the studios.

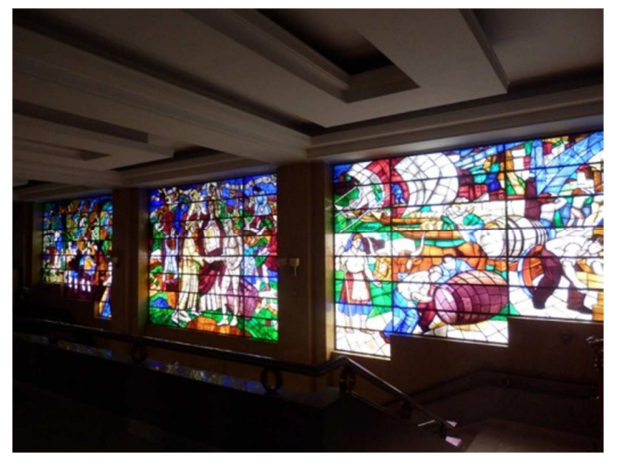

Figure 5. António Lino Stained glass, Douro House, Régua, 1945.

In the 1950s and 1960s, new Court houses were created in Portugal and the old ones were renovated. At this time artists, painters and sculptors with academic training were called to carry out works, such as tapestry, fresco paintings, sculptures, mosaics and stained glass that would be incorporated into these new government buildings. Lino António received commissions for ten Court houses between 1952 to 1971 [18] he made the cartoons for Guarda (1952), Coimbra (1962), Ponte de Sor (1964) and Seia (1966) are some notable examples.

In 1959, Manuel Cargaleiro (b.1927) created for Block of Free Waters (Bloco das Águas Livres) in Amoreiras an unconventional stained glass window that has a contemporary approach and aesthetic forms, with an abstractionist language. This work is not integrated in a window, it was suspended in the air, like a "colorful and transparent curtain over the landscape; it also inaugurated a purely abstractionist language" [11]. He was later moved to the headquarters of the Fidelidade insurance company, which promotes the work.

In same year, Carlos Calvet made the cartoons for the 
Auditors Court in Lisbon, where the motifs used belong to the iconography of justice.

António Coelho Figueiredo (b.1937) was one of the Fine Arts painters who conceived the elaboration of several cartoons for the Portuguese Courts, namely in Alijó (1966), Fafe (1968). These works were executed in the Antunes studio [7]) and Moura in 1969.

Guilherme Camarinha (1912-1994) was another artist who also designed several cartoons for stained glass windows including the Portuguese Ministry of Finance, in Lisbon in 1959. This artist sought to translate his way of painting subtlety into the stained glass to form a deep atmosphere with a certain poetry and an understanding of the luminosity of these art. In the early-1960s, he also made cartoons for various stained glass windows for the Courts in the north of the country, namely in Vila Nova de Famalicão in 1961 and Amarante in 1963.

Julio Resende in 1971, also conceived a cartoon for the stained glass in the Court house in the town of Vagos.

\section{Beyond Figuration}

In the 1980s and 1990s, some architects favored the use of concrete as a structure and an expressive element of the architectural building, thus establishing a link between concrete and stained glass [13]. During this period, we witness an emergence of contemporary stained glass as many Fine art artists conceive projects that are integrated in this new architecture. According to the historian Sérgio Vieira, Aquino Antunes started in 1979 with a lyric abstractionism work for the Chapel in the Saint Luzia hospital, Viana do Castelo [13].

In 1981, sculptor José Rodrigues (1936-2016) designed the cartoons for the Chapel in the Carmelite Convent, at Patacão in the Algarve. When visualizing the architecture of the chapel we do not associate immediately with the ecclesiastic building, if it was not for the bell tower this could be an ordinary construction (Figure 6). Inside a minimalist geometric language reduced essentially to vertical and horizontal rectangles, symbolizing enclosure grids, where colorless glass marks a punctual presence in a show of blue, pink and brown glass characterizes the composition of the stained glass. It is a stained glass window that has an illusion created by the perspective of the composition, and the magic of light, filtered through colored glass, spreads through the interior of the building (Figure 7). With a geometric shape in a solid construction, the stained glass composition is related to the geometrical structure of the architecture. The tradition of Portuguese ceramic tiles is present here through a repeated pattern [21]. Sérgio Vieira argues that this work is part of the provocative intention of the group "Four Twenty". The "Four Twenty" group were four students, Ângelo de Sousa, Armando Alves, Jorge Pinheiro and José Rodrigues, who obtained the maximum grade (20 points out of 20) on the final classification in 1968, at the Faculty of Fine Arts of the University of Porto thus becoming known with this designation.

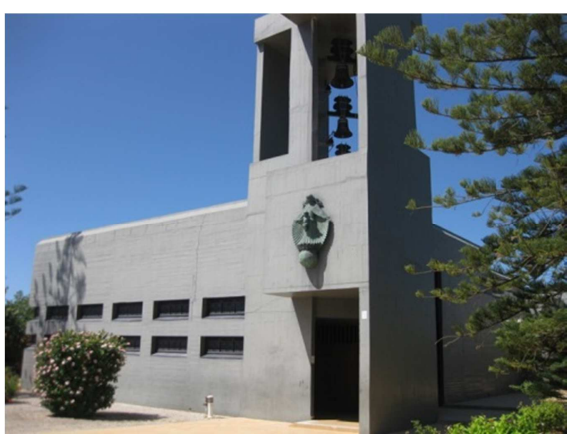

Figure 6. View of the Chapel.

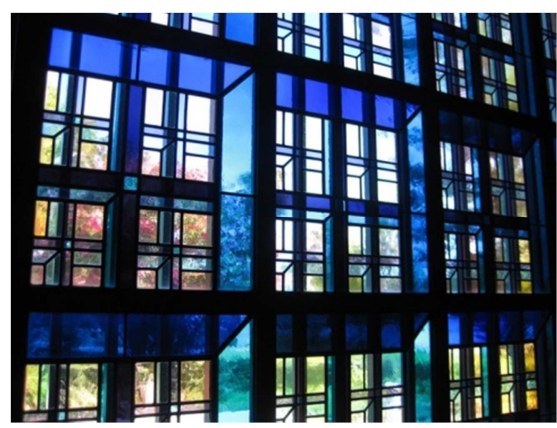

Figure 7. José Rodrigues stained glass, 1981.

In 1986, Amândio da Silva (1923-2000) made an abstract cartoon for the Carmelitas Church, in Porto (Figure 8). These stained glass windows, made in the Antunes workshop, show an abstract composition with irregular shapes. The stained glass window starts at the base with cold colors, the blues, with small entries of warm colors, such as red and orange. At the top you can see geometric shapes (half of cylindrical shapes). However, what is fascinating about these stained glass windows is the fact that at first glance it is an abstract stained glass window, where the lead gutter was used. As we approach the windows, we discover the cement and the thick glass plates, some more prominent than others, and we find that the lead canes were not used in this stained glass, but the dalle de verre technique [7].

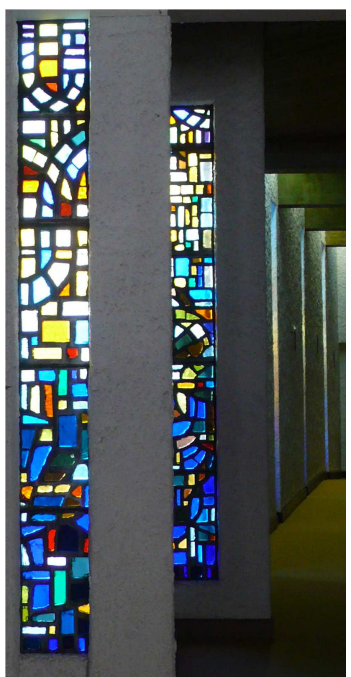

Figure 8. Amândio da Silva stained glass for Carmelitas Church, Porto, 1986. 
In 1996, Júlio Resende, together with artists Manuel Casal Aguiar (b.1941) and Francisco Laranjo (b.1955), made the stained glass windows for Saint Martin Church of Cedofeita, in Porto. The church is characterized by small vertical openings, where the artists introduced a composition of abstract stained glass, overlooking, on the upper floor of the church, orange and red colors and on the lower level blue. A composition dominated by color where an interesting relationship is established between flat colored glass and tinted glass. The light projected through the color of the glass, which expands inside the religious building like a wave of energy, is unforgettable for the spectators who witness it (Figure 9) [7].

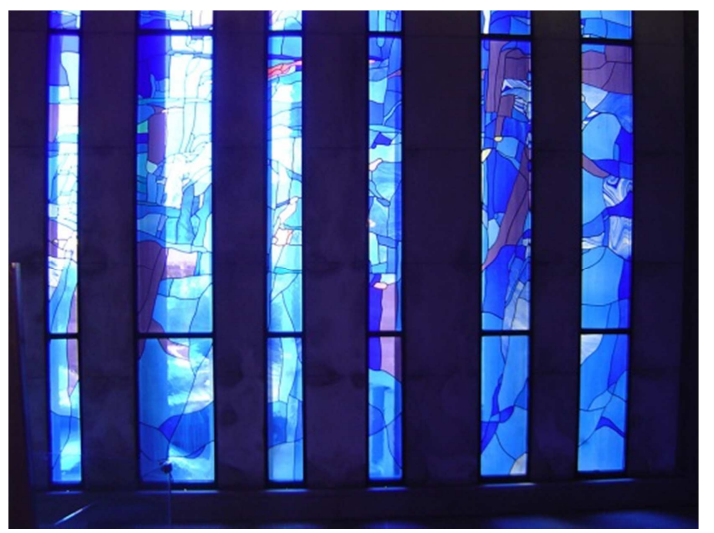

Figure 9. Julio Resende, Manuel Cassal Aguiar and Francisco Laranjo stained glass for Saint Martin Church of Cedufeira, Porto 1996.

In 1993, Domingos Pinho (b.1937) created the cartoons for the large stained glass windows of Saint Antony Church, in Vale de Cambra, from which curvilinear shapes in contrasting colors emerge. Metallic structures generate rectangles and squares, where dynamic compositions are developed, thanks to formal rhythms and chromatic games. The dimensions of the stained glass windows and the spaciousness of the space are conducive to new conceptual readings, where the color is softer and animates the horizontality of the planes covered by the projection of light in the interior of the building (Figure 10). The sensation of the light produced by the stained glass is ethereal, it dissolves in the physical solidity of the gray partitions of the church structure, which are separating the large glass spans (Figure11) [7].

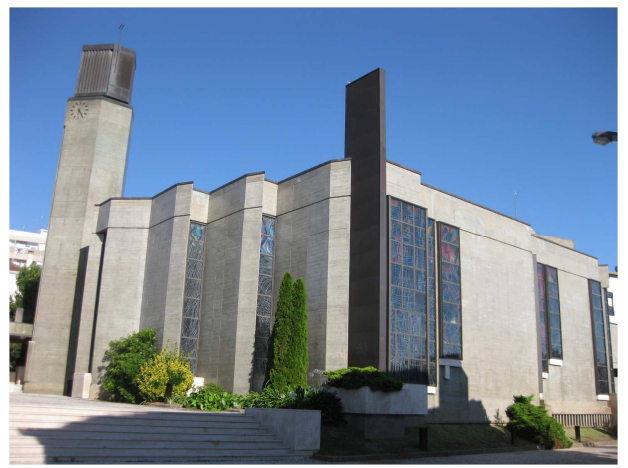

Figure 10. Domingos Pinho stained glass for Saint Antony Church in Vale de Cambra, 1993.

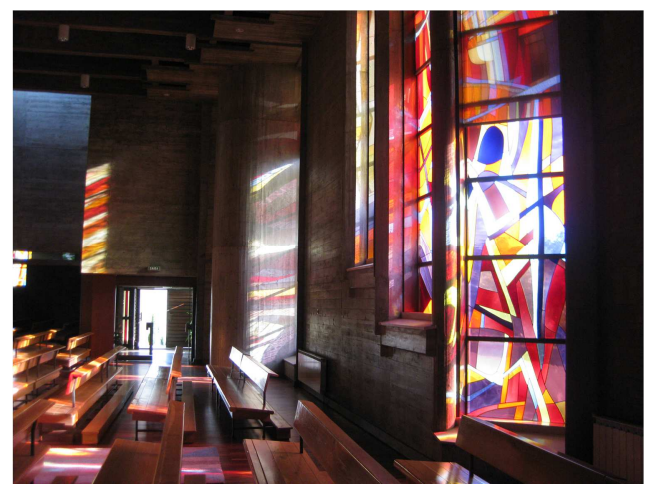

Figure 11. View of the Chapel.

In 2001/02 Eduardo Nery (1938-2013) created a project for the Municipality of Barcelos; a cartoon for one stained glass window, where he creates luminous optical effects, through a pattern of colors with geometric shapes (Figure 12). In reality, Eduardo Nery's artistic expression is characterized by a geometric language of a certain orphism, where circles of colors intertwine with each other, which is also evidenced in his works that also include tapestry, ceramic tiles and mosaic. In fact, interdisciplinary between different art mediums was constant on Nery's works. The stained glass has different colors ranges, where nine color are from the solar spectrum. To this chromatic composition Nery adds three more color ranges [13].

Color is a major factor in the works of Eduardo Nery. The symbology is another, and the stained glass window of the Chapel of Saint Joseph in Fátima, made between 1991-92, is an example where these factors can be seen. Here, Nery uses Zero as a symbol of Chaos, One as the expression of God, Two as the duality, Three as the Holy Trinity, Four as the representative of the Earth, and Five as "Man as a cosmic and spiritual and Christ as its fifth essence" [13].

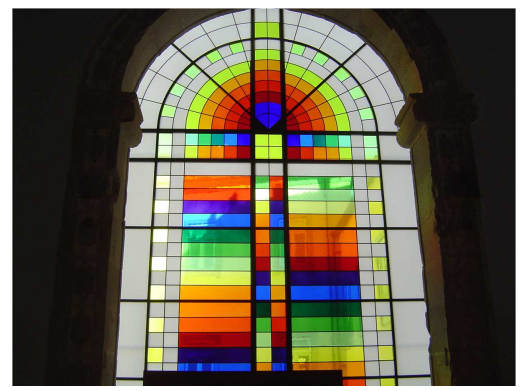

Figure 12. Eduardo Nery stained glass, 2001-02

The stained glass windows in the Cathedral of Vila Real were presented to the public in April 2003. The artist João Vieira (1934-2009) sought to demonstrate the readings of the gospel through the symbology of words (Figure 13). Ernesto Rodrigues speaks of the relationship that is established between the letter, spirit and gospel according to S. João (Saint John). Also mentioning that in this creation a relationship is established with the Verb, and the Verb means words that reads are interpreted by in João Vieira "equal capillaries and not letters" [25]. The artist seeks to create letter games with light. As in his painting works where the artist claims to paint 
with letters, the stained glass windows have the same language. The Bishop, said we can visualize a cross in the rosette and beyond chromatism, the stained glass as indispensable elements to lead the spectator to liturgical symbols [26].

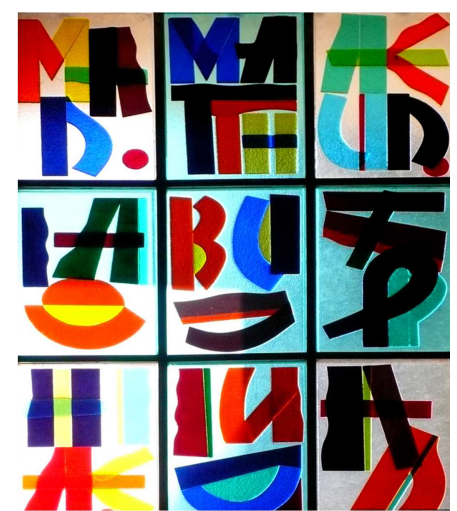

Figure 13. João Vieira stained glass for the Cathedral of Vila Real 2003.

"My writing (drawing, painting) is difficult to read. But God, who writes right by crooked lines (or letters), may help me in this humble imitation. I hope that as my texts, like those of São João, are difficult to read, they are also like his, easy to love" [27].

Using the fusion technique, unusual in religious stained glass, João Vieira gave the stained glass of the cathedral a contemporary character, innovative both in technique and in the theme and iconography of stained glass in Portugal. It is true that other artists also used the symbolism of letters in their formal compositions. John Clark employs a combination of images and letters as symbols in his stained glass, "The Jewish Festivals" (1992) at the Glasgow Synagogue, or "The Bicentenary Windows" (1996) at Stratchclyde University, also in Glasgow [7]. However, this artist's technique remains linked to traditional stained glass with the use of lead in his compositions. In João Vieira, the lead cane, gives way to single glass windows, even though divided into sections of nine rectangles. In these stained glasses the letters appear to float in the composition and in the surrounding space.

In 2008, the artist Francisco Laranjo makes another stained glass (this time solo) for the Holy Family Church in Chaves (northern Portugal). Stained glass windows with an abstract nature, where blues and lilacs predominate, in a composition where verticality prevails. Here and there small green glass and circular shapes in warm colors break this chromaticism [7].

João Aquino Antunes (b.1939) is the current Portuguese artist that dedicate his life to stained glass art. He has a vast artistic production in the area, clearly the most prolific attributed to only one artist in Portugal. In reality, above all those mentioned, João Aquino Antunes is the one that stands out the most in this area, praising stained glass not only in Portugal, but also across borders. With a contemporary approach he learnt the secrets of this technique with his father and started to work with him in the Antunes workshop on the production of the stained glass of other artists. Soon, he established his own creation and not only made the cartoons, but also executed them in his workshop. In 1977, he conceived the cartoons for Gavião Church (Figure 14). With organic shapes, it is an abstract stained glass work organize in section were the blue and the green are the predominant colors (Figure 15).

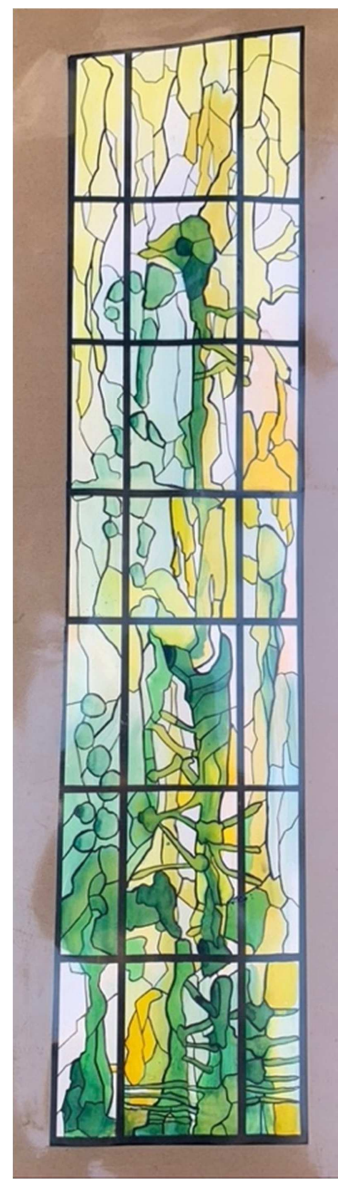

Figure 14. João Aquino Antunes cartoon for Gavião Church 1977.

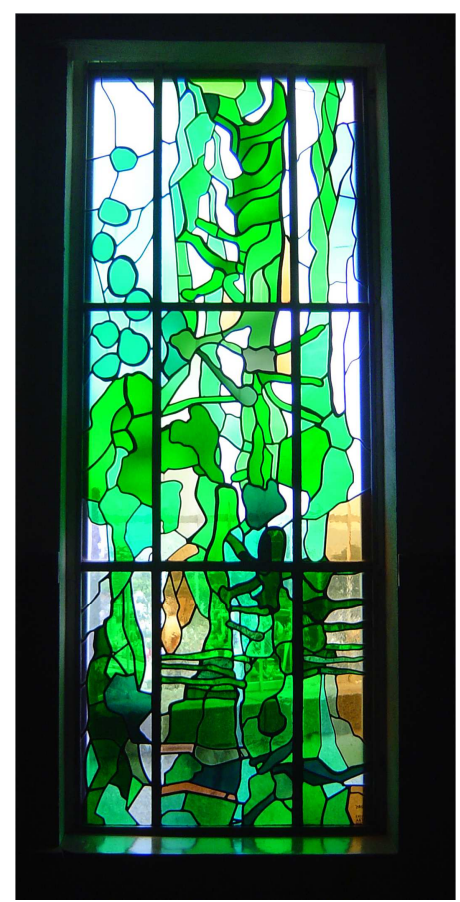

Figure 15. João Aquino Antunes a detail of the stained glass, Gavião church, 1977. 
One of the greatest works produced was the done for a clinical center in Coimbra (Figure 16). This piece is five meters in diameter and eight meters high with and abstract composition with more rectilinear shapes, that are more commonly associated in João Aquino Antunes compositions. It is one of the finest examples of stained glass integration in an architectural building. The artist could have made a standard work, but instead he decided to produce a cylindrical shape that penetrates inside and outside the building becoming an integrated part of the building structure itself. On display in the Museu de Vitral are the cartoon and scale model of this important piece.

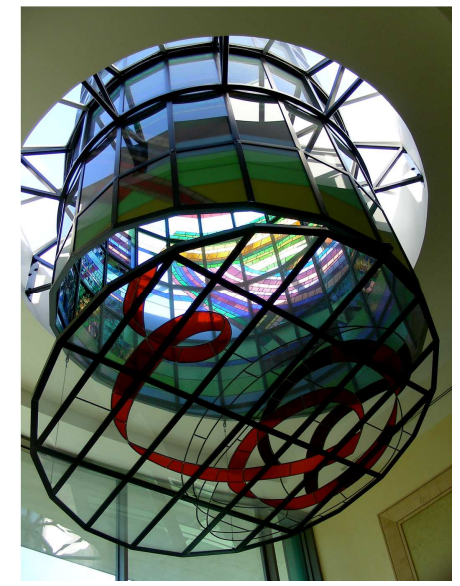

Figure 16. Aquino Antunes stained glass, Coimbra, 2007.

\section{Conclusions}

Portugal has a wide collection of contemporary stained glass work, where Portuguese artists developed and continue to perform to this day, demonstrating that this art form by many connoted with the Middle Ages is still alive.

Stained glass is associated with light, and light is never the same throughout daytime, nor in the seasons, which makes stained glass a unique and unlike any other art medium. Our perception changes according to light variations and the use of colored glass worked (and still works) as a filter that transformed daylight within the architectural space.

In the 20th and 21 st century there is a greater compromise and integration between stained glass and architecture. We are witnessing a development of stained glass in relation to technology, where lead is no longer a requirement of the structural material, but rather a means of expression as part of the artistic composition and where new techniques are used.

This paper confirms that stained glass art is not simply part of the past. Contemporary artists including: Abel Manta, Jorge Barradas, Lino António, Júlio Pomar, Manuel Lapa, Arlindo Rocha, António Lino, Carlos Calvet, Manuel Cargaleiro, Guilherme Camarinha, Isolino Vaz, António Coelho Figueiredo, Vieira da Silva, José Rodrigues, Amândio Silva, Sá Nogueira, Manuel De Francesco, Júlio Resende, Francisco Laranjo, Manuel Casal Aguiar, João Vieira, Eduardo Nery, Domingos Pinho, Augusto Gomes, Aquino Antunes made cartoons. In many of the stained glass windows made by these artists, the pictorial language characteristic of their artistic works, namely in painting on canvas is exquisitely and uniquely.

Today, stained glass is a medium for fine art, where the artist can more freely assert and interpret their own style and identity. It was also attested that Portugal has a prolific present-day production regarding contemporary stained glass that it is far from over.

\section{Acknowledgements}

The author would like to thank to Emma Lochery for the proofreading of this manuscript. This research was funded by VICARTE Research Unit "Glass and Ceramics for the Art" UIDB/00729/2020.

\section{References}

[1] P. J. E. Davis, W. B. Denny, F. F. Hofrichter, J. Jacobs, A. M. Roberts, D. L. Simon, Janson New History of Art, The occident tradition (trad: A Nova História da Arte de Janson. A tradição ocidental), 9th edition, Calouste Gulbenkian Foundation, 2010.

[2] L. Lee, G. Seddon, F. Stephens, Stained Glass. Mitchell Beazley Publishers, 1976.

[3] Almeida, T. Tansparent painting in Laranjo, F; Loureiro, D.; Torres, S.; Almeida, T. (2020); Painting Today: New approaches on process and context, Research Institute on Art, Design and Society. Porto, Portugal.

[4] P. Redol, O mosteiro da Batalha e o vitral em Portugal no século XV e XVI. Batalha Town hall, 2003.

[5] C. Barros, O vitral em Portugal. Séculos XV-XVI. Lisbon: National Press - Mint (Imprensa Nacional - Casa da Moeda), second edition, 1988.

[6] D. F. Ferraz, "A oficina de Ricardo Leone" in O vitral-História, Conservação e Restauro. Lisbon: IPPAR, 2000.

[7] T. Almeida, O vidro como material plástico: transparência, luz cor e expressão. PHD thesis in Aveiro University, Department of Art and Communication, 2011.

[8] Vitorino, Manuel. 2008. Aluz voltou à mais antiga oficina de vitrais. In Newspaper (Jornal de notícias), sunday 19: 18.

[9] Newspaper (Jornal de Noticias e Século): 1927.

[10] Lara, Regina; Almeida, Teresa. (2017). The creative process of applying grisaille in stained glass. Glassac. 5th International Conference on Glass science in Art and conservation, June 2017: 31-33.

[11] R. A. Santos, "Apontamentos para a história do vitral no século $\mathrm{xx}$ " in $\mathrm{O}$ vitral- História, Conservação e Restauro. Lisbon: IPPAR, 2000.

[12] M. A. Maia, Maria Augusta, Almada Negreiros, Um percurso possível. Instituto Português do Património Arquitectónico e Arqueológico. Lisbon: National Press - Mint (Impressa Nacional, Casa da Moeda,) 1993.

[13] S. Vieira, Sérgio "Nery: A inefável geometricidade da luz colorida", in Eduardo Nery, Exposição Retrospectiva Tapeçaria, Azulejo, Mosaico, Vitral [1961-2003], IPM, 2003. 
[14] C. Araújo, Os Vitrais de Júlio Resende na Igreja de Nossa Senhora da Boavista - Porto. Uma leitura teológica, um itinerário espiritual e catequético, como proposta de evangelização. Master thesis in Teologia. Cattolica University, 2019.

[15] S. C. Silva, Júlio Pomar e os vitrais da Igreja da Sagrada Família. Pontinha Parish Council (Junta de Freguesia).

[16] M. Dionísio, Pomar. Europe-America Publications (Publicações Europa-América), 1990.

[17] Boletim da direção-geral dos edifícios e monumentos nacionais. Paço dos Duques de Bragança Guimarães, n120, 1960.

[18] Pascoal, Ana Mehnert. António Lino e a decoração artística para edifícios públicos durante o Estado Novo. In https://www.amap.pt/static/uploads/c/bth/2018/bth2018_1.pdf acess on 5.02.21

[19] M. Brito, 2003. Paço dos Duques de Bragança em Guimarães: metamorfose da imagem na época Contemporânea. Master thesis in History Department, School of Arts and Humanities, Lisbon.

[20] A. Lino, António. “A arte na Idade Média”, Separata especial from Volume IV of proceedings from Congresso Histórico de Guimarães e a sua Colegiada. Barrosa \& Xavier, 1982.
[21] S. Vieira, Para a história do vitral em Portugal no século XXPrincipais oficinas e o papel dos artistas plásticos. Lisboa: Universidade Nova de Lisboa, 2002. Master thesis in Contemporary Art History Department, Nova School of Arts and Humanities, Lisbon.

[22] Castro, Laura. Júlio Resende, ceramic art. National Tile Museum (Museu Nacional do azulejo), 1998.

[23] Porfírio, José Luís. Júlio Resende: As grandes decorações azulejares da Ribeira Negra e do Metropolitanao de sete rios in Castro, Laura. Júlio Resende, ceramic art, National Tile Museum (Museu Nacional do azulejo,) 1998:19-28.

[24] J. Matoso, José, R. H. Silva, S. Leandro, M. Tamagnini, D. Costa. Lino António (1898-1974), Leiria Town Hall (Câmara Municipal de Leiria), 1998: 23-37.

[25] E. Rodigues, "A luz através do texto divino" in Vitrais da Igreja de São Domingos, Vila Real Cathedral. IPPAR, Lisbon, 2003: 37-59.

[26] D. J. Gonçalves, "Os vitrais da Sé de Vila Real”, in Vitrais da Igreja de São Domingos, Vila Real Cathedral. IPPAR, Lisbon, 2003: 9-31.

[27] J. Vieira in Vitrais da Igreja de São Domingos, Vila Real Cathedral. IPPAR, Lisbon, 2003: 61, 62. 